\title{
PENGARUH PENAMBAHAN MADU PADA PAKAN BUATAN DENGAN DOSIS YANG BERBEDA TERHADAP PERFORMA LAJU PERTUMBUHAN RELATIF, EFISIENSI PEMANFAATAN PAKAN DAN KELULUSHIDUPAN IKAN BANDENG (Chanos chanos)
}

\author{
Dini Islamiyah, Diana Rachmawati, Titik Susilowati \\ Departemen Akuakultur Fakultas Perikanan dan Ilmu Kelautan, Universitas Diponegoro
}

\begin{abstract}
ABSTRAK
Penambahan madu dalam pakan buatan mampu memberikan kadar mineral yang dibutuhkan tubuh untuk pertumbuhan. Madu mengandung mineral-mineral yang berfungsi untuk pembentukan sel, pengatur kadar air dalam tubuh dan mengandung antioksidan yang dapat berfungsi untuk ketahanan tubuh. Penelitian ini bertujuan untuk mengetahui pengaruh penambahan madu pada pakan buatan terhadap laju pertumbuhan relatif, efisiensi pemanfaatan pakan dan kelulushidupan ikan bandeng (Chanos chanos). Ikan uji yang digunakan dalam penelitian ini adalah ikan bandeng (nener) dengan ukuran rata-rata bobot awal sebesar $0.8-1.2 \mathrm{~g}$, dan jumlah padat tebar 25 ekor/wadah. Frekuensi pemberian pakan dilakukan 3 kali sehari pada pukul 07.00 WIB, 12.00 WIB dan 17.00 WIB sebesar 5\% dari bobot biomassa. Penelitian ini dilakukan dengan metode eksperimental menggunakan rancangan acak lengkap (RAL), 4 perlakuan dan 3 kali pengulangan. Perlakuan dalam penelitian ini adalah penambahan madu dengan dosis yang berbeda dalam pakan buatan, antara lain: A (0 ml/kg pakan); B (125 ml/kg pakan); C (250 ml/kg pakan) dan D (375 ml/kg pakan). Hasil penelitian menunjukkan bahwa penambahan madu pada pakan buatan memberikan pengaruh nyata $(\mathrm{P}<0,05)$ terhadap pertumbuhan bobot mutlak (W), laju pertumbuhan relatif (RGR), efisiensi pemanfaatan pakan (EPP) dan protein efesiensi rasio (PER) serta tidak berpengaruh nyata $(\mathrm{P}>0,05)$ terhadap Survival Rate (SR). Perlakuan D (375ml $/ \mathrm{kg} \mathrm{pakan)}$ merupakan perlakuan terbaik yang memberikan nilai tertinggi pada W $(249,53 \pm 2,75 \mathrm{~g})$; RGR $(24,55 \pm 0,17 \%$ /hari); EPP $(47,36 \pm 0,50 \%)$, dan PER $(1,81 \pm 0,08 \%)$. Kualitas air pada media pemeliharaan yang meliputi suhu, DO, pH, amonia dan salinitas tergolong pada kisaran yang sesuai untuk budidaya ikan bandeng (C. chanos).
\end{abstract}

Kata kunci: Pakan, Bandeng, Dosis, Madu.

\begin{abstract}
The quality of the feed is good aside from the content of protein as well as from mineral contained therein. Addition of honey in artificial fish feed could gave some minerals which needed for growing up. Honey contains minerals that served for the establishment of a regulator, cell water content in the body and contains antioxidants that could served for the resilience of the body. This research aims to know the effect of the addition of honey in the feeding -made against relative growth rate, efficiency of feed utilization and the survival rate of milkfish (Chanos chanos). The fish used in this research is the milkfish (C. chanos) in size with an average weight of $0.8-1.2 \mathrm{~g}$ to the amount of dense stocking 25 -ind /cages. Frequency of feeding was done in 3 times a day at 7:00 PM GMT, 12:00 PM GMT and 17:00 PM GMT amounting to 5\% of the weight of biomass. This research was conducted with the experimental method using random design complete (RAL), with the 4 treatments and repetition as much as 3 times. The treatments in this study is the addition of honey with different doses in artificial feed such as $\mathrm{A}(0 \mathrm{ml} / \mathrm{kg}$ of feed); B (125 ml/kg of feed); $\mathrm{C}$ (250 ml/kg of feed) and $\mathrm{D}(375 \mathrm{ml} / \mathrm{kg}$ of feed). The results showed that the addition of honey in artificial feed has significant $(\mathrm{P}<$ 0.05 ) in absolutally weight (W), relative growth rate (RGR), efficiency of feed utilization (EPP) and protein effeciency ratio (PER) and has no significant $(\mathrm{P}>0.05)$ for survival rate $(\mathrm{SR})$. The treatment $\mathrm{D}$ is the best once which has gave the highest value on the W $(249,53 \pm 2,75 \mathrm{~g})$; RGR $(24,55 \pm 0,17 \% /$ day $)$; $\operatorname{EPP}(47,36 \pm 0,50 \%)$, and PER (1.81 $\pm 0.08 \%)$. Water quality maintenance of media such as temperature, DO, pH, salinity and ammonia have in range that is suitable for the cultivation of milkfish (C. chanos).
\end{abstract}

Keywords: Feed, Honey, Milkfish, Doses. 


\section{PENDAHULUAN}

Ikan bandeng (C. chanos) merupakan salah satu komoditas yang potensial dalam usaha budidaya, selain itu ikan bandeng tahan terhadap perubahan lingkungan. Ikan ini juga merupakan jenis ikan ekonomis dan banyak diminati masyarakat untuk dikonsumsi maupun sebagai umpan ikan. Ketersediaan pakan yang cukup, tepat waktu, berkesinambungan, memenuhi kecukupan gizi, disukai oleh ikan dan mudah dicerna sangat penting dalam proses budidaya. Pakan yang berkualitas sangat mendukung dalam proses pertumbuhan.

Faktor utama yang mempengaruhi pertumbuhan dan kesehatan ikan adalah pakan (Khasani, 2013). Pakan yang baik mengandung nutrisi yang seimbang untuk pertumbuhannya dan mengandung antioksidan untuk kekebalan tubuhnya. Madu merupakan senyawa aktif yang berperan untuk melindungi sel normal dan menetralisir radikal bebas yang dapat menghambat stres oksidatif pada sel. Madu juga mengandung berbagai mineral seperti kalium, kalsium, magnesium dan natrium. Mineral-mineral tersebut mempunyai fungsi sebagai pembentukan sel dan pengatur kadar air dalam tubuh (Mukti et al., 2009). Nutrisi yang terkandung dalam madu diantaranya karbohidrat, protein, asam amino, fenol, vitamin dan mineral. Senyawa komplek ini sangat diperlukan terutama untuk memacu pertumbuhan (Afroz et al.,2016).

Permasalahan yang ditemukan adalah masih lambatnya laju pertumbuhan dan rendahnya efisiensi pakan. Untuk itu diperlukan upaya untuk meminimalisir biaya pada pakan, perlu dilakukan manajemen teknologi dalam membantu proses budidaya. Penambahan madu dalam pakan buatan diharapkan mampu untuk membantu dalam kegiatan budidaya.

Penelitian ini bertujuan untuk mengetahui pengaruh penambahan madu pada pakan buatan terhadap laju pertumbuhan relatif, efesiensi pemanfaatan pakan dan kelulushidupan ikan bandeng (C. chanos); dan untuk mengetahui dosis terbaik penambahan madu pada pakan yang memberikan pertumbuhan relatif dan kelulushidupan terbaik ikan bandeng (C.chanos). Penelitian ini dilaksanakan pada tanggal 17 Maret 2017 - 3 Mei 2017 di tambak tradisional Dusun Roban Timur Kecamatan Tulis, Kabupaten Batang.

\section{METODE PENELITIAN}

Ikan yang digunakan dalam penelitian ini adalah ikan bandeng $(C$. chanos) stadia nener dengan bobot 
individu rata-rata 0.8-1.2 g dengan padat tebar 25 ekor/wadah. Ikan uji berasal dari Slamaran Kelurahan Krapyak lor, Kota Pekalongan. Ikan uji di seleksi terlebih dahulu sesuai ukuran dan tidak cacat. Ikan mulai di adaptasikan dalam tambak selama 7 hari untuk penyesuaian lingkungan baru dan pakan nya.

Pakan uji yang diberikan untuk ikan bandeng selama penelitian adalah pakan komersil berbentuk pellet dengan ukuran diameter $1 \mathrm{~mm}$. Madu murni yang dihasilkan dari lebah sebagai substitusi pakan nya. Aquadest sebagai pengencer madu dan larutan agar rumput laut sebagai binder atau pengikat madu agar tidak larut dalam media. Prosedur pembuatan pakan mengacu pada penelitian Mukti (2009) dengan cara pakan ditimbang sebanyak $1000 \mathrm{~g}$ untuk tiap-tiap perlakuan yaitu sebanyak empat kali, lalu menyiapkan dosis madu $0 \mathrm{ml}, 125 \mathrm{ml}, 250 \mathrm{ml}, 375$ ml,(dalam perlakuan A,B,C,D) selanjutnya menyiapkan aquadest untuk pengencer madu sebanyak $100 \mathrm{ml}$ pada tiap-tiap perlakuan. Campuran madu dan aquadest dicampurkan ke dalam pakan sampai rata dengan cara disemprot atau spray, setelah itu, pembuatan adonan agar-agar, yaitu dengan komposisi satu sachet jelly yang berisi 7 gram dengan $600 \mathrm{ml}$ air, setelah adonan agar-agar jadi, didinginkan, kemudian campuran pakan pellet, madu dan aquadest dicampurkan ke adonan agaragar dengan cara diaduk, selanjutnya dikeringkan dibawah sinar matahari lalu diangin-anginkan.

Data analisis proksimat setiap perlakuan dapat dilihat pada (Tabel 1). Pemberian pakan pada ikan bandeng sebanyak 5\% dari bobot biomassa. Frekuensi pemberian pakan 3 kali yaitu pada pagi, siang dan sore hari (07.00, 12.00 dan 17.00 WIB).

Tabel 1. Data Analisis Proksimat Pakan

\begin{tabular}{ccccccc}
\hline Dosis Madu (ml/Kg Pakan) & Air & Abu & Protein & Lemak & Karbohidrat & Total \\
\hline 0 & 8,43 & 9,82 & 41,71 & 3,18 & 36,86 & 100,00 \\
125 & 19,52 & 8,17 & 30,63 & 4,33 & 37,35 & 100,00 \\
250 & 20,33 & 7,43 & 27,61 & 3,9 & 40,73 & 100,00 \\
375 & 21,92 & 7,01 & 26,14 & 2,9 & 42,03 & 100,00 \\
\hline
\end{tabular}

Keterangan : Hasil Analisa Proksimat Pakan Uji di Laboratorium Processing Teknologi Hasil Perikanan, Fakultas Perikanan dan Ilmu Kelautan, Universitas Diponegoro (2017)

Penelitian ini dilakukan dengan metode eksperimen menggunakan Rancangan Acak Lengkap (RAL) dengan
4 perlakuan dan 3 kali ulangan. Perlakuan dalam penelitian ini adalah penambahan 
madu dengan dosis yang berbeda pada pakan buatan, diantaranya yaitu:

A : Penambahan dosis madu $0 \mathrm{ml} / \mathrm{kg}$ pakan

B : Penambahan dosis madu $125 \mathrm{ml} / \mathrm{kg}$ pakan

C : Penambahan dosis madu $250 \mathrm{ml} / \mathrm{kg}$ pakan

D : Penambahan dosis madu $375 \mathrm{ml} / \mathrm{kg}$ pakan

\section{Pengumpulan data}

Variabel yang diukur meliputi pertumbuhan bobot mutlak (W), laju pertumbuhan relatif (RGR), efisiensi pemanfaatan pakan (EPP), protein efisiensi ratio (PER), dan kelulushidupan (SR).

Data kualitas air yang diukur meliputi DO, $\mathrm{pH}$, suhu, amonia dan salinitas.

\section{Pertumbuhan bobot mutlak}

Pertumbuhan bobot mutlak dihitung dengan menggunakan rumus Effendi (1979) sebagai berikut:

$$
\mathrm{W}=\mathrm{Wt}-\mathrm{Wo}_{\mathrm{o}}
$$

dimana:

$$
\begin{aligned}
\mathrm{W}= & \text { Pertumbuhan mutlak ikan uji }(\mathrm{g}) \\
\mathrm{Wo}= & \text { Bobot ikan uji pada awal } \\
& \text { pemeliharaan }(\mathrm{g}) \\
\mathrm{Wt}= & \text { Bobot ikan uji pada akhir } \\
& \text { pemeliharaan }(\mathrm{g})
\end{aligned}
$$

\section{Efisiensi pemanfaatan pakan}

Nilai efisiensi pemanfaatan pakan (EPP) dapat ditentukan dengan rumus Tacon (1987) sebagai berikut:

$$
\mathrm{EPP}=\frac{\mathrm{W}_{\mathrm{t}}-\mathrm{W}_{\mathrm{o}}}{\mathrm{F}} \times 100 \%
$$

dimana:

$$
\begin{aligned}
\mathrm{EPP}= & \text { Efisiensi pemanfaatan pakan }(\%) \\
\mathrm{W}_{\mathrm{t}}= & \text { Bobot total ikan uji pada akhir } \\
& \text { penelitian }(\mathrm{g}) \\
\mathrm{W}_{\mathrm{o}}= & \text { Bobot total ikan uji pada awal } \\
& \text { penelitian }(\mathrm{g}) \\
\mathrm{F}= & \text { Jumlah pakan yang dikonsumsi } \\
& \text { selama penelitian }(\mathrm{g})
\end{aligned}
$$

\section{Protein efisiensi rasio}

Nilai protein efisiensi rasio (PER) dapat ditentukan dengan menggunakan rumus Tacon (1987) sebagai berikut:

$$
\mathrm{PER}=\frac{\mathrm{W}_{\mathrm{t}}-\mathrm{W}_{\mathrm{o}}}{\mathrm{Pi}} \times 100 \%
$$

dimana:

$$
\begin{aligned}
\text { PER = } & \text { Protein efisiensi rasio }(\%) \\
\mathrm{W}_{\mathrm{t}}= & \text { Bobot total ikan bandeng pada } \\
& \text { akhir penelitian }(\mathrm{g}) \\
\mathrm{W}_{\mathrm{O}}= & \text { Bobot total ikan bandeng pada } \\
& \text { awal penelitian }(\mathrm{g})
\end{aligned}
$$


$\mathrm{Pi}=$ Jumlah pakan yang dikonsumsi $\mathrm{x}$ $\%$ protein pakan

\section{Laju pertumbuhan relatif}

Menurut De Silva dan Anderson (1995) dalam Subandiyono dan Hastuti (2016), laju pertumbuhan relatif atau relative growth rate (RGR) ikan dihitung menggunakan rumus sebagai berikut:

$$
\mathrm{RGR}=\frac{\mathrm{W}_{\mathrm{t}}-\mathrm{W}_{\mathrm{o}}}{\mathrm{W}_{\mathrm{o}} \times \mathrm{t}} \times 100 \%
$$

dimana:

$$
\begin{aligned}
\mathrm{RGR}= & \text { Laju pertumbuhan relatif }(\% / \text { hari }) \\
\mathrm{W}_{\mathrm{t}=} & \text { Bobot total ikan bandeng pada } \\
& \text { akhir pemeliharaan }(\mathrm{g}) \\
\mathrm{W}_{\mathrm{O}}= & \text { Bobot total ikan bandeng pada } \\
& \text { awal pemeliharaan }(\mathrm{g}) \\
\mathrm{t}= & \text { Waktu pemeliharaan (hari) }
\end{aligned}
$$

\section{Kelulushidupan}

Kelulushidupan atau survival rate (SR) dihitung untuk mengetahui tingkat kematian ikan uji selama penelitian, kelulushidupan dapat dihitung berdasarkan rumus Effendi (1997):

$$
\mathrm{SR}=\frac{\mathrm{N}_{\mathrm{t}}}{\mathrm{N}_{0}} \times 100 \%
$$

dimana:

$\mathrm{SR}=$ Tingkat kelulushidupan ikan (\%)

$$
\begin{aligned}
\mathrm{N}_{\mathrm{t}}= & \text { Jumlah ikan uji pada akhir } \\
& \text { penelitian (ekor) } \\
\mathrm{N}_{0}= & \text { Jumlah ikan uji pada awal } \\
& \text { penelitian (ekor) }
\end{aligned}
$$

\section{Parameter Kualitas air}

Parameter data kualitas air yang diukur meliputi $\mathrm{DO}, \mathrm{pH}$, suhu, amonia dan salinitas. DO diukur dengan menggunakan DO meter, $\mathrm{pH}$ diukur dengan $\mathrm{pH}$ universal, suhu diukur dengan termometer dan untuk pengukuran amonia dan salinitas, sampel air diukur di laboratorium teknik lingkungan dan budidaya perairan, UNDIP.

\section{Analisis Data}

Analisa data yang dilakukan meliputi pertumbuhan bobot mutlak (W), efisiensi pemanfaatan pakan (EPP), protein efisiensi ratio (PER), laju pertumbuhan relatif (RGR), kelulushidupan (SR), dan kualitas air. Variabel yang didapatkan kemudian dianalisis menggunakan analisis ragam (ANOVA) selang kepercayaan 95\%, sebelum dilakukan ANOVA data terlebih dahulu dilakukan uji normalitas, uji homogenitas, dan uji addivitas guna mengetahui bahwa data bersifat normal, homogen dan aditif untuk dilakukan uji lebih lanjut yaitu analisa ragam. Apabila dalam analisis ragam diperoleh beda nyata 
$(\mathrm{P}<0,05)$, maka dilakukan uji wilayah ganda Duncan untuk mengetahui perbedaan antar perlakuan. Data kualitas air dan kelulushidupan (SR) dianalisis secara deskriptif.

\section{HASIL}

Hasil penelitian pengaruh penambahan madu pada pakan buatan ikan bandeng (C. chanos) terhadap pertumbuhan bobot mutlak (W), laju pertumbuhan relatif (RGR), efisiensi pemanfaatan pakan (EPP), dan protein efisiensi ratio (PER) tersaji pada Tabel 2.

Hasil analisis ragam menunjukan bahwa penambahan madu pada pakan buatan untuk ikan bandeng memberikan pengaruh yang nyata $(\mathrm{P}<0,05)$ terhadap nilai bobot mutlak (W), laju pertumbuhan relatif (RGR), efisiensi pemanfaatan pakan (EPP), dan protein efisiensi rasio (PER) namun tidak berpengaruh nyata $(\mathrm{P}>0,05)$ terhadap nilai kelulushidupan (SR). Hasil pengukuran parameter kualitas air pada media ikan bandeng (C. chanos) selama pemeliharaan tersaji pada Tabel 3.

\section{PEMBAHASAN}

Performa pertumbuhan pada ikan bandeng (C. chanos) yang diamati adalah pertumbuhan bobot mutlak (W) dan laju pertumbuhan relatif (RGR).

Tabel 2. Nilai Rata-rata W, EPP, PER, dan RGR pada Ikan Bandeng (C. chanos) Selama Pemeliharaan

\begin{tabular}{ccccc}
\hline \multirow{2}{*}{$\begin{array}{c}\text { Dosis Madu } \\
(\mathrm{ml} / \text { Kg pakan })\end{array}$} & $\mathrm{W}(\mathrm{g})$ & RGR $(\% /$ hari $)$ & PER $(\%)$ & EPP $(\%)$ \\
\cline { 2 - 5 } & $188,65 \pm 2,19^{\mathrm{d}}$ & $18,93 \pm 0,89^{\mathrm{d}}$ & $1,03 \pm 0,02^{\mathrm{c}}$ & $37,89 \pm 0,23^{\mathrm{d}}$ \\
0 & $209,89 \pm 1,42^{\mathrm{c}}$ & $20,56 \pm 0,09^{\mathrm{c}}$ & $1,37 \pm 0,03^{\mathrm{b}}$ & $41,70 \pm 0,26^{\mathrm{c}}$ \\
250 & $232,56 \pm 2,33^{\mathrm{b}}$ & $22,50 \pm 0,33^{\mathrm{b}}$ & $1,77 \pm 0,03^{\mathrm{ab}}$ & $44,88 \pm 0,62^{\mathrm{b}}$ \\
375 & $249,53 \pm 2,75^{\mathrm{a}}$ & $24,55 \pm 0,17^{\mathrm{a}}$ & $1,81 \pm 0,08^{\mathrm{a}}$ & $47,36 \pm 0,50^{\mathrm{a}}$ \\
\hline
\end{tabular}

Tabel 3. Kualitas Air pada Media Ikan Bandeng (C. chanos) selama Pemeliharaan

\begin{tabular}{lccc}
\hline \multicolumn{1}{c}{ Parameter Kualitas Air } & Kisar-an & $\begin{array}{c}\text { Kelayakan Optimal } \\
\text { Menurut Pustaka }\end{array}$ & Pustaka \\
\hline Suhu $\left({ }^{0} \mathrm{C}\right)$ & $28-30$ & $28-30$ & $\mathrm{a}$ \\
Oksigen terlarut $(\mathrm{mg} / \mathrm{l})$ & $4.3-6.32$ & $7-8$ & $\mathrm{a}$ \\
$\mathrm{pH}$ & $7-8$ & $6.5-9$ & $\mathrm{a}$ \\
Amonia $(\mathrm{mg} / \mathrm{l})$ & $0.04-0.07$ & $0.1-0.6$ & $\mathrm{~b}$ \\
Salinitas (ppt) & $5.37-15$ & $5-25$ & $\mathrm{c}$ \\
\hline
\end{tabular}

Keterangan : (a) Rangka dan Andi (2010); (b) Lesmana (2004); dan (c) World Wildlife Foundation perikanan Indonesia (2014)

Hasil analisis ragam menunjukkan bahwa penambahan madu pada pakan buatan memberikan pengaruh nyata
$(\mathrm{P}<0,05)$ terhadap pertumbuhan bobot mutlak dan laju pertumbuhan relatif ikan bandeng ( $C$. chanos). Berdasarkan hasil 
tersebut dapat dinyatakan bahwa pengaruh pertumbuhan bobot mutlak dan laju pertumbuhan relatif ikan bandeng yang diperoleh dari madu melalui penambahan pada pakan buatan ikan bandeng $(C$. chanos) mampu mencukupi kebutuhan untuk energi dan pertumbuhan ikan bandeng (C. chanos $)$ terlihat dari kesesuaian pada kandungan nutrisi pakannya. Data analisis proksimat dapat dilihat pada (Tabel 1). Menurut Spikadhara et al. (2012) bahwa kesesuaian jenis pakan sangat mempengaruhi suatu organisme untuk dapat tumbuh dan berkembang biak. Pakan yang sesuai dengan kebutuhan ikan akan dimanfaatkan dengan baik untuk pertumbuhan. Ikan bandeng (C. chanos) merupakan ikan jenis herbivora yang mana ikan tersebut mampu memanfaatkan karbohidrat lebih banyak sebagai sumber energi sehingga kandungan protein yang rendah dalam pakan nya mampu dimanfaatakan secara optimal untuk pertumbuhan. Berbeda dengan ikan jenis karnivora dan omnivora yang memanfaatakan protein sebagai pertumbuhan dan sumber energi. Pertumbuhan terjadi karena energi yang digunakan untuk aktifitas sudah terpenuhi sehingga nutrisi seperti protein akan dimanfaatkan lebih untuk pertambahan bobot. Menurut Choi et al. (2016) pemanfaatan protein pakan berkorelasi dengan energi yang ada pada pakan. Energi diperoleh dari katabolisme protein saat energi pakan tidak mencukupi atau protein pakan berlebih. Pakan dikatakan efektif saat pakan yang dimakan ditampilkan dalam pertumbuhan seperti memperbaiki dan membangun jaringan sebanyak mungkin dengan jumlah terkecil yang dirubah menjadi energi.

Hasil tertinggi terdapat pada perlakuan D (madu $375 \mathrm{ml} / \mathrm{kg}$ pakan) dengan pertumbuhan bobot mutlak sebesar $249,53 \pm 2,27 \mathrm{~g}$, dan laju pertumbuhan relatif sebesar $24,55 \pm 0,17 \% /$ hari, sedangkan nilai terendah terjadi pada perlakuan A (kontrol) dengan pertumbuhan bobot mutlak sebesar $188,65 \pm 2,19 \mathrm{~g}$ dan laju pertumbuhan relatif sebesar $18,93 \pm 0,89 \% /$ hari. Pertumbuhan suatu organisme berhubungan dengan kebutuhan energi yang ada didalam tubuhnya. Pertumbuhan akan terjadi apabila kebutuhan energi suatu organisme telah terpenuhi. Menurut Suprayudi et al. (2011) dalam penelitiannya menyatakan bahwa kelebihan energi setelah dipakai untuk pemeliharaan, metabolisme dasar dan aktifitas akan disimpan dalam tubuh yang diekpresikan dalam bentuk pertumbuhan. Madu mengandung karbohidrat yang mana dapat dimanfaatkan oleh ikan bandeng sebagai 
sumber energi. Menurut Rahma et al. (2017) bahwa komponen utama madu adalah karbohidrat sebanyak 82,49 g. Madu juga mengandung air, kalori, lemak, sodium, protein, vitamin $\mathrm{B} 12, \mathrm{C}, \mathrm{A}, \mathrm{D}, \mathrm{E}$, dan asam pantotenat, kalsium, besi, seng, magnesium, kalium, tembaga, krom, mangan, dan pospor.

Pakan yang baik adalah pakan yang memiliki kualitas dan kuantitas yang baik yang dibutuhkan oleh tubuh untuk kelangsungan hidup dan pertumbuhan. Pakan yang berkualitas mengandung nutrisi yang baik dan seimbang yang terdiri dari protein, karbohidrat, lemak, vitamin dan mineral. Menurut Afroz et al. (2016) menyatakan bahwa madu mengandung senyawa komplek (kimia dan bio-kimia) diantara nya gula-gulaan (karbohidrat), protein, asam amino, fenol, vitamin, mineral dan antioksidan. Antioksidan yang terdapat pada madu mempunyai fungsi sebagai ketahanan tubuh. Madu mengandung kaya akan mineral yang baik untuk pertumbuhan dan kesehatan. Mineral berfungsi dalam tubuh hewan, termasuk pembentukan struktur utama dan juga dibutuhkan untuk pertumbuhan. Hal tersebut diperkuat oleh Mukti (2009) yang menyatakan bahwa madu mempunyai fungsi penting dalam tubuh hewan termasuk dalam pembentukan struktur utama untuk menunjang pertumbuhan. Mineral yang terdapat pada madu juga dibutuhkan untuk pertumbuhan dan sintasan pada makhluk hidup, karena pada madu mengandung antioksidan yang baik untuk kesehatan. Hasil terendah yang terjadi pada perlakuan A diduga karena komposisi nutrisi pada perlakuan A tidak sesuai dengan kebutuhan nutrisi ikan bandeng. Pakan yang sesuai mampu untuk menunjang pertumbuhan. Pertumbuhan akan terjadi apabila pada pakan nya mengandung suatu campuran yang seimbang antara asam amino esensial dan non-esensial, suplemen feed, karbohidrat, vitamin, lemak dan mineral. Salah satu faktor utama yang memengaruhi laju pertumbuhan dan kesehatan ikan adalah pakan, baik aspek kandungan nutrisi maupun kuantitas. Menurut Kacaniova et al. (2012), madu mengandung senyawa aktif yang dapat menghentikan aktivitas bakteri yang dapat menyebabkan penyakit dan senyawa komplek seperti vitamin, enzim, asam organik dan zat-zat gizi mineral seperti mangan, seng, tembaga dan selenium yang diduga berperan untuk pertumbuhan, melindungi sel normal dan menetralisir radikal bebas.

Nilai rata-rata bobot mutlak dari tertinggi hingga terendah antara lain pada 
perlakuan D sebesar 249,53 g, kemudian menurun pada perlakuan $\mathrm{C}$ sebesar 232,56 $\mathrm{g}$, dan diikuti oleh perlakuan B sebesar 209,89 g dan nilai terendah pada perlakuan A sebesar 188,65 g, sedangkan nilai ratarata laju pertumbuhan relatif dari yang tertinggi hingga terendah antara lain pada perlakuan D sebesar 24,55 $\pm 0,17 \%$ /hari, kemudian menurun pada perlakuan $\mathrm{C}$ sebesar 22,50 $\pm 0,33 \%$ /hari, dan diikuti oleh perlakuan B sebesar 20,56 $\pm 0,09 \%$ /hari dan nilai terendah terjadi pada perlakuan $\mathrm{A}$ sebesar $18,93 \pm 0,89 \% /$ hari. Perbedaan nilai rerata tersebut diduga karena perbedaan konsentrasi dosis madu yang ditambahkan, sehingga ikan pada masing-masing perlakuan hanya dapat memanfaatkan ketersediaan nutrisi pakan pada masingmasing perlakuan tersebut. Menurut Sartika et al. (2013) bahwa laju pertumbuhan organisme perairan bervariasi tergantung pada ketersediaan makanan yang dimanfaatkan untuk kelangsungan hidup dan pertumbuhan. Menurut Rahma et al. (2017) dalam penelitian nya menyatakan bahwa madu alami dapat dimanfaatkan sebagai bahan tambahan untuk meningkatkan laju pertumbuhan pada populasi pakan alami $B$. plicatilis. Konsentrasi madu yang berbeda menyebabkan laju pertumbuhan populasi B. plicatilis yang bervariasi.
Pemanfaatan pakan pada ikan bandeng ( $C$. chanos) yang diamati adalah efisiensi pemanfaatan pakan (EPP) dan protein efisiensi rasio (PER) ikan bandeng. Hasil analisis ragam menunjukkan bahwa penambahan madu pada pakan buatan berpengaruh nyata $(\mathrm{P}>0,05)$ terhadap efisiensi pemanfaatan pakan dan rasio efisiensi protein ikan bandeng ( $C$. chanos). Berdasarkan hasil ini dapat dinyatakan bahwa pengaruh efisiensi pemanfaatan pakan dan protein efisiensi rasio yang diperoleh dari konsentrasi madu yang ada pada pakan tersebut, yang mana pakan buatan yang ditambahkan madu tersebut di sukai oleh ikan bandeng dan mudah di cerna dengan baik, sehingga pakan yang diberikan tersebut dapat termanfaatkan secara efisien serta dapat mempengaruhi nilai efesiensi pemanfaatan pakan. Kandungan protein yang terdapat dalam pakan mampu mencukupi kebutuhan ikan untuk tumbuh dengan optimal. Protein dankelebihan sumber energi setelah dipakai untuk metabolisme dan aktifitas akan disimpan dalam tubuh yang diekpresikan dalam bentuk pertambahan bobot dan panjang. Sumber energi untuk aktivitas dan metabolisme telah memanfaatkan karbohidrat dari madu yang di tambahkan. Pemanfaatan pakan terjadi pada saat proses dicernanya pakan oleh tubuh sehingga akan menghasilkan 
bobot tubuh yang meningkat. Menurut Lestari et al.(2013) bahwa keefisienan penggunaan pakan menunjukkan nilai pakan yang dapat merubah menjadi pertambahan berat pada ikan.

Ikan bandeng (C. chanos) merupakan ikan herbivora (pemakan tumbuhan) yang relatif mampu memanfaatkan karbohidrat lebih banyak sebagai sumber energi dibandingkan ikan karnivora dan omnivora. Kandungan karbohidrat yang terdapat pada pakan uji dapat dilihat pada (Tabel 1). Ikan bandeng sebagaimana hewan air lainnya, untuk memperoleh pertumbuhan yang optimal membutuhkan asupan makanan dengan unsur-unsurnya seperti protein, karbohidrat, lemak, vit-min dan lain-lain yang dapat mencukupi kebutuhan untuk pertumbuhan. Berdasarkan hasil dari analisa proksimat (Tabel 1), dapat dilihat bahwa perlakuan D mempunyai kandungan protein paling rendah dari semua perlakuan. Namun, kandungan karbohidrat dalam pakan (perlakuan D) mampu dimanfaatkan lebih banyak sebagai sumber energi, sehingga protein nya dapat dimanfaatkan secara optimal untuk pertumbuhan. Hal ini diperkuat oleh Usman et al. (2014) yang menyatakan bahwa ikan herbivora (pemakan tumbuhtumbuhan) relatif mampu memanfaatkan karbohidrat lebih banyak sebagai sumber energi dibandingkan ikan karnivora dan omnivora, sehingga pakannya berpeluang memiliki kandungan protein yang lebih rendah untuk tetap tumbuh dengan optimal.

Tinggi nya kadar karbohidrat dalam pakan disebabkan karena penambahan madu dalam pakan nya, karena berdasarkan data dari Unitated States Department of Agriculture (USDA) tahun 2012 menyatakan bahwa pada madu mengandung 38\% fruktosa; $31 \%$ glukosa; $7,2 \%$ maltose; $4,2 \%$ trisakarida dan beberapa polisakarida; $1,5 \%$ sukrosa; $17,1 \%$ air dan $0,5 \%$ mineral, vitamin dan enzim. Hal ini dapat mendukung untuk pakan ikan herbivora karena pada ikan herbivora lebih memanfaatkan pakan dengan kandungan nabati dan karbohidrat yang tinggi, sehingga protein yang rendah lebih dapat dimanfaatkan secara efisien untuk pertumbuhan.

Ikan bandeng (C. chanos) mempunyai kebutuhan nutrisi yang berbeda-beda setiap ukurannya. Semakin besar ukuran ikan, maka kebutuhan protein nya semakin turun. Ikan uji yang digunakan pada penelitian ini berukuran 0.8-1.2 g. Menurut Aslamyah et al. (2012), Kebutuhan protein pakan ikan bandeng dengan berbagai ukuran tubuhnya antara 
lain ikan bandeng dengan ukuran 0,010,035 g membutuhkan protein berkisar dari 60-52\%; ukuran 0,04 g membutuhkan protein 40-32\%, dan ukuran 0,5-1,00 g membutuhkan protein $30-20 \%$. Semakin besar ukuran ikan kebutuhan protein semakin menurun.

Nilai rata-rata tingkat efisiensi pemanfaatan pakan yang tertinggi hingga terendah yaitu perlakuan D sebesar $47,36 \pm 0,50 \%$, kemudian menurun pada perlakuan C sebesar 44,88 $\pm 1,5 \%$, lalu diikuti oleh perlakuan B sebesar $41,70 \pm 1,49 \%$ dan nilai terendah pada perlakuan A sebesar 37,89 $\pm 0,61 \%$, sedangkan nilai rata-rata protein efisiensi rasio pada perlakuan dari yang tertinggi hingga terendah adalah perlakuan D sebesar $1,81 \pm 0,08 \%$, kemudian menurun pada perlakuan $\mathrm{C}$ sebesar $1,77 \pm 0,03 \%$, dan diikuti oleh perlakuan B sebesar $1,37 \pm 0,03 \%$ dan nilai terendah pada perlakuan A sebesar 1,03 $\pm 0,02 \%$. Perbedaan tingkat pemanfaatan pakan disebabkan oleh perbedaan antara kebutuhan energi dan komposisi nilai nutrisi pakan yang diberikan pada setiap perlakuan. Pertumbuhan terjadi karena memiliki nilai efisensi pemanfaatan pakan yang tinggi dan protein efesiensi rasio yang tinggi. Menurut Iskandar dan Elrifadah (2015) bahwa nilai efisiensi pakan diperoleh dari hasil perbandingan antara pertambahan bobot tubuh ikan dengan jumlah pakan yang dikonsumsi oleh ikan selama masa pemeliharaan. Berdasarkan pernyataan diatas dapat diketahui bahwa pakan akan efisien apabila dapat diserap tubuh lalu menghasilkan pertambahan bobot.

Berdasarkan hasil pengamatan mengenai pemanfaatan pakan pada penelitian ini menunjukkan bahwa pakan yang di konsumsi ikan dapat dimanfatkan dengan baik pada dosis D (madu 375 $\mathrm{ml} / \mathrm{kg}$ pakan) yang merupakan hasil tertinggi yaitu sebesar $47,36 \pm 0,50 \%$ dan protein efesiensi rasio sebesar $1,81 \pm 0,08 \%$. Penambahan madu pada pakan buatan ikan bandeng berguna sebagai sumber energi dan penunjang pertumbuhan yang mana akan berdampak pada peningkatan efisiensi pakan. Bandeng merupakan ikan perenanng aktif dan suka hidup bergerombol. Aktivitas berlebih pada ikan bandeng banyak memanfaatkan sumber karbohidrat pada pakan nya sebagai sumber energi. Madu yang mengandung sebagian besar karbohidrat mampu mencukupi kebutuhan kalori untuk ikan bandeng, kemudian kandungan protein yang terdapat pada pakan dapat dimanfaatkan secara optimal untuk pertumbuhan. Nilai terendah efisiensi 
pemanfaatan pakan terjadi pada perlakuan A (kontrol) sebesar $37,89 \pm 0,61 \%$ dan juga pada nilai protein efisiensi rasio sebesr $1,03 \pm 0,02 \%$. Penggunaan karbohidrat sebagai sumber energi tergolong rendah pada perlakuan A sehingga protein yang terdapat pada pakan nya tidak efisien untuk pertumbuhan akan tetapi lebih dimanfaatkan sebagai sumber energi untuk aktivitas dan metabolisme. Menurut Marzuqi et al. (2012) bahwa nilai efisiensi pemanfataan pakan yang rendah menunjukkan bahwa ikan tersebut memerlukan pakan dengan jumlah yang lebih banyak untuk dapat meningkatkan beratnya karena hanya sebagian kecil energi dari pakan yang diberikan digunakan oleh ikan untuk pertumbuhan, selain itu kepadatan ikan dan kadar protein dalam pakan juga dapat mempengaruhi efisiensi pemanfaatan pakan.

Hasil analisis ragam kelulushidupan ikan bandeng (C. chanos) menunjukkan bahwa penambahan madu pada pakan buatan ikan bandeng tidak berpengaruh nyata $\quad(\mathrm{P}>0,05) \quad$ terhadap tingkat kelulushidupan. Nilai rata-rata tingkat kelulushidupan tertinggi adalah perlakuan $\mathrm{B}$, perlakuan $\mathrm{C}$ dan perlakuan $\mathrm{D}$ sebesar $100,00 \%$. Adapun nilai terendah adalah perlakuan A sebesar 98.67 $\pm 2.31 \%$. Tingkat kelulushidupan yang rendah diduga akibat penanganan selama penelitian berlangsung yang diduga stres, ditandai dengan hilangnya nafsu makan, ikan berenang upnormal dan lesu sehingga lama kelamaan ikan bandeng tersebut mati. Tingkat kelulushidupan yang tinggi diduga ketersediaan makanan dalam penelitian ini cukup untuk memenuhi kebutuhan ikan dalam mempertahankan diri sehingga dapat berpengaruh positif bagi kelulushidupan. Pakan yang baik adalah pakan yang mengandung nutrisi yang seimbang dan tidak menyebabkan racun pada organisme budidaya. Nutrisi pada madu berperan penting dalam formulasi pakan karena berperan besar dalam ketahanan tubuh, selain itu faktor internal dan eksternal juga dapat mempengaruhinya.

Hasil terendah adalah perlakuan A yang mana pakan tidak diberi dosis madu (0 $\mathrm{ml} / \mathrm{kg}$ pakan) sehingga saat penanganan selama penelitian yang meliputi berbagai pengukuran seperti penimbangan bobot ikan, menjadikan ikan tersebut mati akibat stres. Menurut Latumahina et al.(2011) bahwa madu dapat menghambat stres oksidatif dengan kandungan nutrisinya yang mengandung senyawa aktif yang berperan sebagai antioksidan, seperti: vitamin, enzim, asam organik, flavonoid, betakaroten dan zat-zat gizi mineral seperti 
mangan, seng, tembaga dan selenium yang diduga berperan untuk melindungi sel normal dan menetralisir radikal bebas yang dapat menghambat stres oksidatif pada sel.

Dilihat dari nilai kelulushidupan nya, perlakuan yang ditambahkan dosis madu pada pakan nya menghasilkan nilai kelulushidupan yang sama tinggi nya yaitu 100,00\%. Hal ini juga diduga karena pakan yang diberikan mengandung nutrisi yang baik seperti antioksidan yang mampu melindungi sel dari radikal bebas. Menurut Latumahina et al. (2011) menyatakan bahwa senyawa-senyawa antioksidan dalam madu berperan untuk melindungi sel normal, menetralisir radikal bebas, dan menghambat stress. Kandungan nutrisi dalam madu yang berfungsi sebagai antioksidan adalah vitamin $\mathrm{A}$, vitamin $\mathrm{C}$, vitamin E, enzim, flavonoid dan beta karoten.

\section{KESIMPULAN DAN SARAN}

\section{Kesimpulan}

Penambahan madu pada pakan buatan mempunyai pengaruh nyata terhadap laju pertumbuhan relatif, efisiensi pemanfaatan pakan. Komposisi dosis terbaik penambahan madu pada pakan buatan adalah pada dosis madu $375 \mathrm{ml} / \mathrm{kg}$ pakan.

\section{Saran}

Disarankan untuk melakukan penelitian lebih lanjut mengenai dosis madu yang lebih tinggi dengan waktu yang lebih lama.

\section{UCAPAN TERIMA KASIH}

Terima kasih penulis ucapkan kepada pemilik tambak tradisional Roban Timur, Kabupaten Batang, Bapak Rokiban yang telah menyediakan tempat dan fasilitas untuk pelaksanaan penelitian ini, keluarga dan semua pihak yang telah membantu kelancaran penelitian ini.

\section{DAFTAR PUSTAKA}

Afroz, R., Tanvir, E.M., Zheng, W., and Little, P.J. 2016. Molecular Pharmacology of Honey. J. Of Clinical and Experimental Pharmacology. 6(3): 1-13.

Aslamyah, M.A., Subekti, S., dan Erlina. D.T. 2012. Pengaruh Pemberian Pakan Tambahan (Suplement Feed) Dari Kombinasi Tepung Cacing Tanah (Lumbricus Rubellus) dan Tepung Spirulina Platensis Terhadap Pertumbuhan Dan Retensi Protein Benih Ikan Bandeng (Chanos Chanos). J. of Marine and Coastal Science. 1(2): 8190.

Choi, W.M., C. L. Lam, W. Y. Mo dan M. H. Wong. 2016. Upgrading Food Wastes by Means of 
Bromelain And Papain To

Enhance Growth And

Immunity of Grass Carp

(Ctenopharyngodon idella).

Environ Sci Pollut Res,

23:7186-7194.

De Silva, SS. 1987. Finfish Nutrional Research In Asia. Proceeding Of The Second Asian Fish Nutrion Network Meeting. Heinemann, Singapore. 128 p.

Effendi,M.I.1979. Metoda Biologi Perikanan. Penerbit Yayasan Agromedia. Bogor. $58 \mathrm{hlm}$.

1997. Biologi Perikanan. Yayasan Pustaka Nusatama. Yogyakarta. 62 hlm.

Iskandar.R. dan Elrifadah. 2015. Pertumbuhan Dan Efisiensi Pakan Ikan Nila (Oreochromis niloticus) Yang Diberi Pakan Buatan Berbasis Kiambang. 40 (1): 1-7.

Kacaniova, M., Lukas, H., M. Dzugan., and Anna, P. 2012. Microbiological Properties And Antimicrobial Effect Of Slovakian And Polish Honey Having Regard To The Water Activity And Water Content. J.of Microbiology, Biotechnology and Food Sci. 2(1): 272-281.

Khasani, I. 2013. Atraktan pada Pakan Ikan: Jenis, Fungsi, Dan Respons Ikan. Media Akuakultur, 8(2):127-133.

Latumahina, G.J., Kakisina, P. dan Moniharapon, M. 2011. Peran Madu Sebagai Antioksidan Dalam Mencegah Kerusakan Pankreas Mencit (Mus
Musculus) Terpapar Asap Rokok Kretek. J. Kedokteran dan kesehatan. 4(1): 106-116.

Lesmana, D. S. 2004. Kualitas Air untuk Ikan Hias Air Tawar.Penebar Swadaya. Jakarta. 96 hlm.

Lestari. S. Fuji., Salnida Y., dan Zaenal, A. 2013. Pengaruh Formulasi Pakan Berbahan Baku Tepung Ikan, Tepung Jagung, Dedak Halus dan Ampas Tahu Terhadap Pertumbuhan Ikan Nila (Oreochromis niloticus). Jurnal Kelautan. Vol 6 (1):1-8.

Marzuqi, M., N. W. W. Astuti dan K. Suwirya. 2012. Pengaruh Kadar Protein dan Rasio Pemberian Pakan Terhadap Pertumbuhan Ikan Kerapu Macan (Epinephelus fuscoguttatus). J. Ilmu dan Tek. Kelautan Tropis, 4(1):5565.

Mukti, A.T. 2009. Pengaruh Suplementasi Madu Dalam Pakan Induk Betina Terhadap Persentase Jantan Dan Betina, Pertumbuhan Dan Kelangsungan Hidup Benih Lobster Air Tawar Red Claw (Cherax Quadricarinatus). J. Akuakultur Indonesia. 8(1): $37-45$.

Mukti, A.T., A.S. Mubarok, dan Adde, E. 2009. Pengaruh Penambahan Madu Dalam Pakan Induk Jantan Lobster Air Tawar Red Claw (Cherax Quadricarinatus) Terhadap Rasio Jenis Kelamin Larva. J. Ilmiah Perikanan dan Kelautan. 1(1): 37-42.

Rahma, R., S.A.E. Rahimi, dan Siska, M. 2017. Pengaruh Penggunaan 
Madu Untuk Pengkayaan

Pakan Terhadap Laju

Pertumbuhan Rotifera (B.

plicatilis). J. Ilmiah Kelautan

dan Perikanan. 2(1): 206-212.

Rangka, N.A. dan Andi, I.J.A. 2010. Teknologi Budidaya Ikan Bandeng di Sulawesi Selatan: 187-202.

Spikadhara, E.D.T., S. Subekti dan M.A. Almasjah. 2012. Pengaruh Pemberian Pakan Tambahan (Suplement Feed) dari Kombinasi Tepung Cacing Tanah (Lumbricus rubellus) dan Tepung Spirulina platensis Terhadap Pertumbuhan dan Retensi Protein Benih Ikan Bandeng (Chanos chanos). Jurnal of Marine and Coastal Science, 1(2): $81-90$.

Subandiyono dan Hastuti, S. 2016. Beronang serta Prospek Budidaya Laut di Indonesia. LPPMP UNDIP Press. Semarang, $86 \mathrm{hlm}$.

Suprayudi, M.A., W. Dimahesa, D. Jusadi, M. Setiawati, J. Ekasari. 2011.
Suplementasi Crude Enzim Cairan Rumen Domba pada Pakan Berbasis Sumber Protein Nabati dalam Memacu Pertumbuhan Ikan Nila (Oreochromis Niloticus). Jurnal Iktiologi Indonesia, 11(2): 177-183.

Tacon, A. J. 1987. The Nutrition and Feeding Formed Fish and Shrimp. A Training Manual Food and Agriculture of United Nation Brazilling, Brazil. 108 p.

Usman, L. Asda, dan E. Sutikno. 2014. Suplementasi Crude Enzim Papain Dalam Pakan Pembesaran Ikan Baronang $(S$. guttatus). J. Fish. Sci. XVI(1): 10-16.

World Wildlife FoundationIndonesia.2014. Budidaya Ikan Bandeng (Chanos chanos) pada TambakRamah Lingkungan. Jakarta Selatan.WWFIndonesia. $12 \mathrm{hlm}$. 